\title{
KOMUNIKASI DALAM TRANSFORMASI BUDAYA PERUSAHAAN
}

\author{
Susie Perbawasari dan Yanti Setianti \\ Fakultas Ilmu Komunikasi Universitas Padjadjaran Bandung \\ Jl. Raya Bandung Sumedang Km.21 Jatinangor, Jawa Barat - 45363 \\ Telp, Fax/HP : (022) 7796954, 7794122/0811214790 dan 08562121843 \\ email: susieperbawasari@yahoo.com dan yantisetianti@yahoo.com \\ Naskah diterima tanggal 8 Mei 2013, disetujui pada tanggal 24 Juni 2013
}

\section{COMMUNICATION IN CORPORATE CULTURE TRANSFORMATION}

\begin{abstract}
PT Dahana (Persero) which was originally a monopoly company has been changed into a company that has competitors not only from within the country but also from foreign companies, therefore it takes effort to transform corporate culture so that employee can adjust their behavior with the company's vision to be a global player. The objective of this study is to investigate the comprehension of PT. Dahana's employees about the recent and the previous corporate cultures within the organization. This study used qualitative research approach with constructivist paradigm, and the type chosen was case studies. According to the study, it was revealed that the old values in the previous corporate culture were understood by the employees as culture with kinship, strict leadership, relaxed work ethos, bureaucratic, less-competitiveness, less client-orientation, and not based on competencies. Meanwhile, the new values in the recent culture were comprehend as culture with high discipline value, system of rewards and punishments, efficiency, based on competency, prioritizing educational levels, but without adequate role models.
\end{abstract}

Keywords: communication, transformation, corporate culture.

\begin{abstract}
Abstrak
PT Dahana (Persero) yang semula merupakan perusahaan monopoli mengalami perubahan menjadi perusahaan yang memiliki pesaing tidak hanya dari dalam negeri tetapi juga dari perusahaan asing, untuk itu diperlukan upaya transformasi budaya perusahaan supaya perilaku karyawannya dapat menyesuaikan dengan visi perusahaan yakni menjadi pemain global. Penelitian ini bertujuan untuk mengetahui pemahaman karyawan mengenai nilai budaya lama dan pemahaman karyawan mengenai nilai budaya baru perusahaan. Pendekatan penelitian yang digunakan adalah kualitatif, dengan paradigma konstruktivisme, dan jenis studi adalah studi kasus. Hasil penelitian mengungkapkan bahwa karyawan memahami nilai budaya lama perusahaan sebagai budaya kekeluargaan, kepemimpinan, santai, birokrasi, kurang kompetitif, kurang client oriented, tidak berbasis kompetensi. Karyawan memahami budaya baru perusahaan sebagai budaya yang memiliki nilai disiplin, adanya reward dan punishment, efisien, berdasarkan kompetensi, mengutamakan pendidikan tetapi kurang adanya keteladanan.
\end{abstract}

Kata kunci: komunikasi, transformasi, budaya perusahaan. 


\section{PENDAHULUAN}

Komunikasi merupakan aktivitas dasar manusia. Dengan berkomunikasi manusia dapat berhubungan satu sama lain dalam berbagai aktivitas di semua tempat, mulai dari rumah, tempat bekerja, di dalam masyarakat, dan di manapun manusia berada. Komunikasi sangatlah penting, demikian juga dalam suatu perusahaan. Keberhasilan perusahaan bergantung pada kemampuan para karyawan dan manajemen berkomunikasi secara efektif.

Komunikasi yang efektif diperlukan ketika perusahaan menyampaikan normanorma, aturan-aturan, dan nilai-nilai yang dianut oleh perusahaan supaya terjadi pemahaman yang sama. Menjadi anggota karyawan perusahaan berarti menjadi bagian dari budaya perusahaan.

PT Dahana (Persero) merupakan suatu perusahaan yang bergerak di bidang produksi bahan peledak. Menurut sejarah perusahaan, Dahana pada awalnya merupakan perusahaan monopoli, yang keberadaannya dimulai dengan pembangunan pabrik dinamit ( $N G$ based) pada tahun 1966 di lingkungan pangkalan TNI-AU Tasikmalaya. Selaku Badan Usaha Milik Negara (BUMN). PT Dahana (Persero) tidak terlepas dari faktor eksternal seperti lingkungan dan tuntutan zaman yang dapat mengakibatkan persaingan semakin meningkat.

Fungsi utama budaya, yaitu untuk adaptasi terhadap lingkungan eksternal dan proses integrasi internal. Untuk itu, perusahaan harus dapat beradaptasi terhadap lingkungan. Hal inilah yang mendasari perusahaan melakukan transformasi budaya.

Selain tantangan bisnis yang merupakan faktor eksternal, tantangan yang lebih berat datang dari lingkungan internal yakni perilaku karyawan yang terbiasa tanpa pesaing dan berada di lingkungan AURI. Ketika terjadi perubahan lingkungan dan adanya tuntutan zaman, perilaku lama karyawan masih terbawa padahal perusahaan sudah bukan perusahaan yang monopoli, sehingga manajemen beranggapan bahwa nilai-nilai yang dianut sudah tidak sesuai lagi dengan lingkungan. Untuk itu, PT Dahana (Persero) menilai perlu mengubah budaya perusahaan dengan cara melakukan transformasi budaya perusahaan.

Berdasarkan hal tersebut, penulis tertarik untuk meneliti transformasi budaya perusahaan di PT Dahana (Persero). Penelitian ini diarahkan untuk memperoleh gambaran mengenai pemahaman karyawan terhadap nilai-nilai budaya, baik budaya lama maupun budaya baru.

Permasalahan yang akan ditelaah dalam penelitian ini adalah hal-hal yang berkenaan dengan situasi dan kondisi subjektif dari pelaku transformasi budaya perusahaan yakni karyawan ketika mengonstruksi budaya perusahaan. Berbagai perspektif teoretis dipergunakan dalam penelitian ini sebagai panduan dan bekal bagi penulis untuk membedah dan menganalisis realitas ini. Penulis memaparkan teori-teori yang relevan dan digunakan dalam membahas serta menganalisis hasil temuan data di lapangan. Teori-teori tersebut adalah Teori Budaya Organisasi, Teori Konstruksi Sosial atas Realitas, dan Teori Interaksi Simbolik.

Penelitian ini bertujuan untuk mengetahui pemahaman karyawan mengenai nilai budaya lama dan pemahaman karyawan mengenai nilai budaya baru perusahaan.

Penelitian ini diharapkan memberikan manfaat kepada PT Dahana (Persero) untuk mengimplementasikan suatu budaya baru dalam perusahaan dan melakukan transformasi budaya perusahaan.

\section{LANDASAN KONSEPTUAL}

\section{Komunikasi Organisasi}

Organisasi dapat dipandang dari dua pendekatan yaitu pendekatan objektif dan pendekatan subjektif, tergantung cara pandang kita. Pendekatan objektif mengatakan bahwa organisasi adalah sesuatu yang bersifat fisik dan konkret, dan merupakan sebuah struktur dengan batasbatas yang pasti yang merangkum orangorang, hubungan-hubungan, tujuan-tujuan, dan menganggap organisasi sebagai wadah. Sementara, pendekatan subjektif memandang 
organisasi sebagai kegiatan yang dilakukan orang-orang. Organisasi terdiri dari tindakantindakan, interaksi, dan transaksi yang melibatkan orang-orang. Berdasarkan pandangan objektif, organisasi berarti struktur; berdasarkan pandangan subjektif, organisasi berarti proses (Pace dan Faules, 2001).

Komunikasi organisasi adalah "perilaku pengorganisasian" yang terjadi dan bagaimana mereka yang terlibat dalam proses itu berinteraksi dan memberi makna atas apa yang sedang terjadi. Definisi lain mengatakan bahwa komunikasi organisasi adalah proses penciptaan makna atas interaksi yang menciptakan, memelihara, dan mengubah organisasi (Pace dan Faules, 2001).

Dalam penelitian tentang transformasi budaya perusahaan, pendekatan yang dipergunakan adalah pendekatan subjektif atau interpretif, di mana organisasi dipandang sebagai suatu proses yaitu proses perubahan budaya yang meliputi proses perubahan perilaku atau tindakan, proses interaksi, serta proses transaksi yang melibatkan seluruh anggota perusahaan.

\section{Budaya Organisasi dan Budaya Perusahaan}

Budaya berperan sebagai penentu batasbatas; artinya, budaya menciptakan perbedaan atau yang membuat unik suatu organisasi dan membedakannya dengan organisasi lainnya, budaya juga memuat rasa identitas suatu organisasi.

Budaya didefinisikan oleh Zwell dalam Wibowo (2010) sebagai berikut:

Budaya adalah cara hidup orang yang dipindahkan dari generasi ke generasi melalui berbagai proses pembelajaran untuk menciptakan cara hidup tertentu yang paling cocok dengan lingkungannya. Budaya merupakan pola asumsi dasar bersama yang dipelajari kelompok melalui pemecahan masalah adaptasi eksternal dan integrasi internal.

Adapun penerapan budaya tersebut di dalam organisasi, menjadi budaya organisasi. Budaya organisasi adalah sebuah sistem makna bersama yang dianut oleh para anggota yang membedakan suatu organisasi dari organisasi-organisasi lainnya. Sistem makna bersama ini adalah sekumpulan karakteristik kunci yang dijunjung tinggi oleh organisasi. Dengan kata lain, budaya adalah sebuah sistem makna bersama.

Menurut pendapat Schein dalam Moeljono (2003) budaya korporat mengacu ke suatu sistem makna bersama yang dianut oleh anggota-anggota yang membedakan organisasi itu terhadap organisasi-organisasi lain. Vecchio memberi definisi budaya organisasi sebagai nilai-nilai dan normanorma bersama yang terdapat dalam suatu organisasi dan mengajarkan kepada pekerja yang datang. Adapun menurut Kreitner dan Kinicki budaya organisasi adalah nilai-nilai dan keyakinan bersama yang mendasari identitas perusahaan (Wibowo, 2010).

\section{Transformasi Budaya Organisasi}

Budaya organisasi merupakan sistem makna bersama terhadap nilai-nilai primer yang dianut bersama dan dihargai organisasi, yang berfungsi menciptakan pembedaan yang jelas antara satu organisasi dengan organisasi lainnya. Dengan demikian transformasi budaya organisasi adalah perubahan terhadap nilai-nilai primer yang dianut bersama dan dihargai organisasi, yang berfungsi menciptakan pembedaan yang jelas antara satu organisasi dengan organisasi lainnya.

\section{Kerangka Pemikiran}

Suatu perusahaan dibentuk untuk mencapai suatu tujuan tertentu dan keberhasilannya ditentukan oleh kemampuannya untuk mencapai tujuan tersebut. Keberhasilan perusahaan dalam mencapai tujuan sangat ditentukan oleh kinerja perusahaan yang sangat dipengaruhi oleh faktor eksternal dan faktor internal.

Faktor eksternal adalah segala sesuatu yang berasal dari luar, namun mempunyai pengaruh besar terhadap perusahaan dan budayanya. Kecenderungan global yang semakin kompetitif berpengaruh kuat 
terhadap budaya perusahaan. Apabila tidak dapat merespons pengaruh global, akan berdampak pada kesulitan perusahaan.

Faktor internal adalah sumber daya yang diperlukan untuk mewujudkan kinerja perusahaan dan nilai-nilai budaya yang dianut oleh segenap sumber daya manusianya. Kedua faktor tersebut, baik eksternal maupun internal, merupakan realitas perusahaan yang menuntut perusahaan untuk menciptakan dan mempertahankan nilai-nilai budaya yang dianut bersama sebagai pedoman untuk berperilaku bagi seluruh anggota perusahaan. Teori Budaya Organisasi berasumsi bahwa: "Anggota organisasi menciptakan dan mempertahankan perasaan yang dimiliki bersama mengenai realitas organisasi, yang berakibat pada pemahaman yang lebih baik mengenai nilai-nilai sebuah organisasi" (West dan Turner, 2007). Sementara Teori Konstruksi Sosial atas Realitas dalam salah satu asumsi dasarnya menyatakan bahwa: pemahaman terhadap realitas yang tersusun secara sosial membentuk banyak aspek penting dalam kehidupan, seperti aktivitas berpikir dan berperilaku (Koeswarno, 2008).

Pemahaman yang baik oleh seluruh anggota perusahaan terhadap nilai budaya dapat membantu mereka dalam bertindak untuk membantu perusahaan mencapai tujuan serta membantu perusahaan dalam menciptakan identitas perusahaan, karena budaya merupakan cerminan dari tampilan perusahaan. "Budaya bervariasi dalam organisasi-organisasi yang berbeda, dan interpretasi tindakan dalam budaya ini juga beragam" (West dan Turner, 2007).

Selain sebagai identitas yang membedakan dari perusahaan lain, budaya perusahaan juga merupakan perekat antar karyawan, oleh sebab itu perusahaan harus memiliki budaya yang kuat, sehingga perusahaan dan karyawannya akan memiliki perilaku yang seiring sejalan serta memiliki keyakinan kolektif yang dapat meningkatkan kemampuan mereka bersaing di pasar.

Teori Budaya Organisasi berasumsi bahwa: anggota organisasi menciptakan dan mempertahankan perasaan yang dimiliki bersama mengenai realitas organisasi (West dan Turner, 2007). Dengan demikian, nilai budaya tidak hadir dengan sendirinya tetapi diciptakan dan dipertahankan untuk diketahui dan dipahami oleh seluruh anggota perusahaan.

Komunikasi merupakan sumber penting dalam proses perubahan dan pembelajaran. Sebagai suatu proses, transformasi budaya perusahaan memerlukan adanya proses sosialisasi dan implementasi yang melibatkan seluruh individu yang ada di dalam perusahaan.

\section{METODE PENELITIAN}

Penelitian ini menggunakan paradigma konstruktivisme, pendekatan kualitatif, jenis studinya adalah studi kasus.

Pendekatan subjektif mengasumsikan bahwa pengetahuan bersifat interpretif. Perspektif interpretif merupakan pandangan subjektif mengenai realitas dan sifat manusia. Perspektif ini berpendapat bahwa dunia sosial tidak eksis dalam pengertian yang konkret, tetapi dibangun oleh interaksi dan pengesahan secara konsensus para individu (Pace dan Faules, 2001).

Perspektif interpretif (subjektif) melihat budaya organisasi sebagai proses-proses pembentukan pemahaman yang membentuk realitas organisasi. Pendekatan subjektif memandang sebuah organisasi sebagai kegiatan yang dilakukan orang-orang yang bersifat aktif.

Subjek penelitian ini adalah pimpinan dan karyawan di lingkungan PT Dahana (Persero) serta orang-orang yang terkait dengan transformasi budaya perusahaan. Adapun pihak yang terkait langsung dalam proses transformasi budaya ini adalah AOC, Champion, dan karyawan. Objek penelitian ini adalah budaya perusahaan di PT Dahana (Persero).

Penelitian ini menggunakan pendekatan kualitatif. Pendekatan kualitatif bersifat lentur dan terbuka dengan menekankan analisis induktif (empirico inductive) (Suprayogo dan Tabroni, 2001). Berpikir secara induktif, yaitu menangkap berbagai fakta atau fenomenafenomena sosial, melalui pengamatan di lapangan, kemudian menganalisisnya dan 
kemudian berupaya melakukan teorisasi berdasarkan apa yang diamati itu (Bungin, 2007).

Penelitian ini merupakan penelitian naturalistik pendekatan interpretif dan metode yang dipergunakan adalah metode studi kasus. Penelitian ini menggunakan metode studi kasus karena ingin memahami fenomena yang terjadi yaitu transformasi budaya di PT Dahana (Persero) yang berlangsung sejak tahun 2007.

Sebagaimana lazimnya perolehan data dalam penelitian kualitatif, data studi kasus dapat diperoleh dari semua pihak yang bersangkutan, baik melalui wawancara, observasi, partisipasi, dan dokumentasi.

Penentuan informan dalam penelitian ini dilakukan secara purposive sampling (sampel bertujuan), karena pemilihan individu didasari pertimbangan. Adapun pertimbangan tersebut kriterianya sebagai berikut:

1. Karyawan tetap, baik pimpinan maupun bawahan;

2. Terlibat langsung dalam proses transformasi budaya perusahaan;

3. Berperan aktif dalam proses transformasi budaya;

4. Menyatakan kesedian untuk menjadi informan penelitian;

5. Memiliki kemampuan untuk mengekspresikan pengalaman dan pemahaman terhadap budaya perusahaan.

Teknik analisis data yang dipergunakan dalam penelitian ini melliputi langkahlangkah sebagai berikut: pertama, reduksi data (data reduction), kedua, penyajian data (data display), dan ketiga, penarikan kesimpulan dan verifikasi (conclusion drawing and verification).

Untuk mengatasi keraguan terhadap hasil penelitian ini, penulis mencoba membangun mekanisme sistem pengujian keabsahan hasil penelitian dengan teknik pemeriksaan yang didasarkan atas sejumlah kriteria yaitu derajat kepercayaan (credibility), keteralihan (transferability), kebergantungan (dependability), dan kepastian (confirmability).

\section{HASIL PENELITIAN DAN PEMBAHASAN}

Setiap organisasi mempunyai normanorma dan nilai-nilai yang dianut untuk mengatur dan mengarahkan perilaku anggotanya, demikian pula PT Dahana (Persero) sebagai salah satu bentuk dari organisasi tentu mempunyai nilai-nilai, kepercayaan, harapan, asumsi, persepsi, norma bersama yang dianut oleh para anggota yang bertujuan untuk membedakan suatu perusahaan dari perusahaan-perusahaan lainnya, menciptakan rasa identitas bagi para anggota perusahaan, serta mempermudah timbulnya komitmen bersama terhadap perusahaan.

Ketika nilai-nilai yang dianut sudah tidak sesuai lagi dengan lingkungan, diperlukan suatu perubahan budaya. Namun demikian, melakukan suatu transformasi budaya tidaklah mudah karena biasanya orang tidak mudah untuk melakukan suatu perubahan dan akan mempertahankan budaya lama yang sudah dianggap baik dan benar. Menurut Thomas dan Inkson, melakukan perubahan budaya berarti melakukan perubahan pola pikir yang sudah tertanam dalam diri masing-masing. Budaya bukan hanya perilaku di permukaan, tetapi sangat dalam ditanamkan dalam diri kita masingmasing (Wibowo, 2010).

Mengubah budaya berarti mengubah nilai-nilai yang dianut bersama. Selain itu, karena budaya menggambarkan pola perilaku suatu organisasi, jadi mengubah budaya berarti mengubah pola perilaku anggota organisasi dari budaya lama ke budaya baru. Untuk itu, penulis menggambarkan pemahaman karyawan tentang budaya lama dan budaya baru perusahaan.

Hasil yang diperoleh menunjukkan bahwa pemahaman karyawan tentang budaya lama maupun budaya baru, mengandung nilai yang positif dan nilai yang negatif. Hal ini tidak terlepas dari aspek-aspek yang memengaruhi suatu proses komunikasi yakni komunikator, pesan, media, komunikan, efek, dan feedback. 


\section{Pemahaman Karyawan tentang Budaya Lama Perusahaan}

Pemahaman karyawan tentang budaya lama dikategorisasikan menjadi tujuh nilai yakni: kekeluargaan, keteladanan pimpinan, santai, birokrasi, kurang kompetitif, tidak client oriented, tidak berbasis kompetensi, dan assessment. Dari ketujuh nilai tadi penulis kelompokkan menjadi dua kategori yaitu nilai yang merupakan nilai budaya yang positif yaitu kekeluargaan dan kepemimpinan, sementara yang merupakan nilai budaya negatif yaitu santai, birokrasi, kurang kompetitif, tidak client oriented, tidak berbasis kompetensi, dan assessment.

Kekeluargaan merupakan salah satu nilai budaya yang positif yang dianut pada budaya lama perusahaan, tidak ada negatifnya dan dulu PT Dahana (Persero) mempunyai budaya kekeluargaan yang baik, seperti yang diungkapkan WBS:

“...kalau dulu kekeluargaannya bagus... yang saya inget budaya yang sangat kental di Dahana itu kekeluargaannya, tapi saya anggap itu bukan budaya yang tidak baik, sudah baik, hanya saja mungkin ada satu sisi menganggap kalau terlalu kekeluargaannya terlalu kental juga profesionalismenya sudah beda, nanti tidak akan bisa maksimal atau gimana" (wawancara dengan WBS, 25 Juni 2012).

Hal tersebut diperkuat oleh pernyataan ES karyawan yang sudah cukup lama bekerja di PT Dahana (Persero) yang beranggapan bahwa kekeluargaan merupakan sesuatu hal yang positif tidak ada negatifnya dan dulu Dahana mempunyai budaya kekeluargaan yang baik, seperti yang diungkapkannya "... kalau dulu kekeluargaannya bagus", (wawancara dengan ES, 26 Juni 2012).

Menurut Luthhans faktor utama yang menentukan kekuatan budaya organisasi adalah kebersamaan dan intensitas (Pabundu, 2006). Kebersamaan dirasakan pada budaya lama, karena kegiatan-kegiatan yang melibatkan semua karyawan dilakukan di satu tempat karena pada saat itu kantor Dahana terpusat di Tasikmalaya sehingga komunikasi yang dilakukan antarsesama anggota perusahaan menjadi lebih intensif dan akrab.
PT Dahana (Persero) ketika berada di bawah kepemimpinan TNI-AU, birokrasinya sangat kental. ES menilai kepemimpinan pada budaya lama itu bagus karena ada aspek keteladanan. "...Ya itulah yang lama itu ke bawahnya bagus...kalau keteladanan yang dulu," (wawancara dengan ES, 26 Juni 2012).

Karyawan lain menilai perhatian pimpinan kepada karyawan level bawah cukup tinggi sebab mereka beranggapan bahwa karyawan level bawah itu merupakan ujung tombak.

Pemimpin yang baik harus dapat mengayomi bawahannya serta mampu menumbuhkan rasa hormat bagi yang dipimpin. Kepemimpinan (Leadership) menjadi salah satu nilai budaya yang dianut oleh PT Dahana (Persero), berdasarkan penjelasannya kepemimpinan bermakna mampu membangun rasa percaya dan hormat dari yang dipimpin yang terlihat dari perilaku jujur, adil, terpercaya, memiliki integritas tinggi, mampu berkomunikasi dengan efektif, konsisten, dan gigih, serta berani mengambil keputusan dengan tegas untuk kepentingan perusahaan, bangsa, dan negara, dengan didukung oleh pengetahuan dan keterampilan sesuai dengan tuntutan tugas dan tanggung jawab (Hasil Raker, 2008).

Pimpinan perusahaan merupakan unsur yang sangat penting dalam proses transformasi budaya perusahaan mengingat pimpinan akan dijadikan contoh oleh bawahannya karena dalam proses perubahan budaya, pimpinan merupakan komunikator yang menyampaikan pesan. Adapun pesan yang disampaikan dalam transformasi budaya adalah pesan yang berkaitan dengan nilai budaya yang dianut perusahaan.

Kekeluargaan dan keteladanan pimpinan merupakan nilai budaya positif yang diciptakan dan perlu dipertahankan bersama oleh seluruh anggota perusahaan sehingga pemahaman mereka tentang nilai budaya perusahaan menjadi lebih baik, sesuai dengan salah satu asumsi dasar dari Teori Budaya Organisasi yang dikemukakan oleh Pacanowsky dan Trujillo yang menyatakan bahwa: "Anggota organisasi menciptakan dan mempertahankan perasaan yang dimiliki bersama mengenai realitas organisasi, yang 
berakibat pada pemahaman yang lebih baik mengenai nilai-nilai sebuah organisasi" (West danTurner, 2007).

Hasil penelitian yang menggambarkan budaya yang negatif dari budaya lama adalah budaya 'santai'. Kategorisasi 'santai' dapat diuraikan melalui wawancara dengan beberapa informan, DBP menggambarkan bagaimana susahnya melakukan transformasi budaya. Meskipun PT Dahana (Persero) sudah melakukan penggantian logo dari yang namanya product driven menjadi market driven company sejak tahun 2000, hal itu tidak mudah karena tidak cukup dengan melakukan adaptasi ke luar tetapi harus juga melakukan penetrasi ke dalam yaitu dengan cara merubah mindset orang, yang tadinya bisa santai, sekarang sudah tidak bisa lagi berperilaku seperti itu. PT Dahana (Persero) sadar bahwa mindset itu harus diubah dan sadar pula bahwa mengubah mindset itu tidak mudah.

Perilaku santai yang dilakukan seorang pimpinan atau karyawan merupakan pesan nonverbal yang dapat ditangkap oleh karyawan lain yang mempunyai efek terhadap karyawan tersebut. Efek tersebut merupakan efek negatif karena kemungkinan ada karyawan yang menangkap sinyal tersebut dan mengikuti perilaku tersebut. Santai sudah menjadi stereotype untuk pegawai negeri dan pada saat itu karyawan PT Dahana (Persero) masih banyak yang berstatus sebagai pegawai negeri. Sinyal nonverbal dari perilaku santai ditangkap dan diikuti oleh karyawan lain yang bukan pegawai negeri (sipil). Hal ini tersirat dari ungkapan EH yang pada saat masuk perusahaan tahun 1991 berstatus sebagai PLP (Pegawai Lokal Perusahaan). “...Kemudian budaya lelet, namanya pegawai negeri, seperti pemda. Sifatnya nongkrong, duduk saja dapat duit" (wawancara dengan EH, 26 Januari 2012).

Pemahaman karyawan tentang budaya lama juga dinilai sebagai budaya yang birokratis mengingat dulu PT Dahana (Persero) dipegang oleh ABRI di Tasikmalaya yang diawali dengan pembangunan pabrik dinamit dengan lisensi Hispano-Suizza. ABRI dikenal dengan birokrasinya yang sangat kuat serta sangat prosedural, seperti yang dikemukakan oleh $\mathrm{EH}$ :

“...Kita ada sedikit sejarah, dulu kita tuh boleh dikatakan dari mulai sistem kinerja kita cenderung menggunakan sistem ABRI, karena kita berada di bawah kepungan ABRI baik masalah kinerja, maupun prosedur, aspek birokrasi terlalu lambat sekali, sangat prosedural..." (wawancara dengan EH, 26 Januari 2012).

Sementara, budaya yang kurang kompetitif terjadi karena dulunya tidak ada persaingan, karena sebelum krisis moneter, PT Dahana (Persero) masih merupakan perusahaan monopoli yang tanpa pesaing, sehingga mereka beranggapan bahwa konsumen yang membutuhkan perusahaan, konsumen yang akan mencari perusahaan, bukan sebaliknya.

Salah seorang karyawan beranggapan bagaimana dulu karyawan itu tidak kompetitif sehingga tidak perlu kerja keras untuk mendapatkan konsumen. Selain kurang kompetitif, budaya lama kurang memperhatikan kepentingan konsumen. ERN menjelaskan bagaimana budaya kerja yang kurang keras karena beranggapan konsumen mau tidak mau pasti akan membeli produk atau menggunakaan jasa perusahaan mereka:

“...dulu monopoli, sama sekali tidak ada pesaing dan sama sekali tidak terlalu workhard untuk mendapatkan konsumen....pasti mau ga mau konsumen ke kita...Tahun 1999 muncul yang namanya UU anti monopoli, tentu diberlakukan untuk semua perusahaan di Indonesia bahwa tidak boleh ada lagi yang monopoli, termasuk Dahana kan kena...." (wawancara dengan ERN, 25 Juni 2012).

Mereka memaknai perusahaan monopoli dengan perusahaan yang tanpa pesaing sehingga mereka beranggapan tidak perlu bekerja keras untuk mendapatkan konsumen dan mereka menganggap konsumenlah yang membutuhkan perusahaan.

Kurangnya kompetitif menurut karyawan disebabkan dulunya Dahana merupakan perusahaan monopoli, sehingga tidak ada pesaing yang berakibat pada pemikiran bahwa konsumenlah yang membutuhkan perusahaan, bukan sebaliknya. Tetapi, lambat laun budaya itu terkikis seiring 
dengan berjalannya waktu, di mana perusahaan berkembang kemudian ditetapkan sebagai industri strategis, adanya era reformasi dan globalisasi yang menuntut perusahaan untuk bersaing dengan perusahaan lain.

Budaya lama yang kurang peduli terhadap konsumen dikemukakan pula oleh YR. Kekurangpedulian terhadap konsumen berakibat pada pelayanan yang kurang optimal terhadap konsumen.

“...di antaranya budaya juga harus ditanamkan karena kita mempunyai care terhadap konsumen kurang, pelayanan terhadap konsumen kurang" (wawancara dengan YR, 26 Januari 2012).

Budaya lama yang kurang peduli terhadap konsumen dikemukakan oleh YR. Kekurangpedulian terhadap konsumen berakibat pada pelayanan yang kurang optimal terhadap konsumen.

“...di antaranya budaya juga harus ditanamkan karena kita mempunyai care terhadap konsumen kurang, pelayanan terhadap konsumen kurang" (wawancara dengan YR, 26 Januari 2012)

Anggapan bahwa konsumen yang membutuhkan perusahaan mengakibatkan karyawannya kurang menghadapi tantangan karena tidak ada pesaing, akibatnya secara otomatis tingkat persaingan pun tidak ada. Akibat dari tidak adanya persaingan adalah tidak adanya inovasi, karena karyawan beranggapan bahwa konsumenlah yang membutuhkan, tanpa inovasi pun konsumen pasti akan menggunakan produk atau menggunakan layanan jasa perusahaan. Kekurangpedulian terhadap konsumen ini berakibat pada pelayanan yang kurang optimal terhadap konsumen. Padahal, pelayanan terhadap konsumen merupakan hal utama dalam menumbuhkan kepercayaan konsumen.

"Bagaimanapun baiknya hasil suatu perusahaan apabila tidak diikuti dengan pelayanan yang optimal, sulit diharapkan untuk dapat diterima oleh konsumen; mengingat konsumen merupakan fokus utama dalam pembahasan mengenai kepuasan dan kualitas jasa. Oleh karena itu, konsumen memegang peranan cukup penting dalam mengukur ke- puasan, baik terhadap produk maupun terhadap pelayanan yang diberikan oleh perusahaan (Moeljono, 2003).

Budaya lama yang juga termasuk ke dalam nilai budaya yang negatif lainnya bahwa pendapatan karyawan itu tidak berdasarkan kompetensi. Padahal, pendapatan merupakan hal utama bagi semua karyawan, mereka bekerja untuk memperoleh pendapatan atau penghasilan namun tidak hanya hak saja yang diperoleh. Mereka pun mempunyai kewajiban yang tidak boleh dilupakan sebagai seorang karyawan perusahaan yaitu bekerja dengan baik yang sesuai dengan peraturan perusahaan dan berperilaku sesuai dengan norma-norma serta nilai-nilai yang dianut perusahaan sehingga tercapai tujuan perusahaan.

Adakalanya karyawan sudah memenuhi hak dan kewajibannya, namun situasi, kondisi, dan lingkungan dapat memengaruhi perilaku karyawan. Misalnya ada yang beranggapan asal datang ke kantor, duduk dapat gaji, karena monopoli tidak perlu mencari konsumen. Perilaku itu terbawa terus meskipun sudah tidak monopoli lagi, sudah masuk era globalisasi, di mana persaingan semakin ketat.

\section{Pemahaman Karyawan tentang Budaya Baru Perusahaan}

Pemahaman karyawan terhadap budaya baru dikategorikan menjadi enam kategori. Dari enam kategori tersebut terdiri dari lima nilai budaya yang positif yaitu disiplin, ada reward dan punishment, efisien, kompetensi dan assessment, dan mengutamakan pendidikan, serta satu nilai budaya yang negatif yaitu kurang adanya keteladanan.

Disiplin merupakan perilaku karyawan yang merupakan efek positif dari diterapkannya nilai budaya baru yang dikomunikasikan kepada seluruh anggota perusahaan melalui berbagai program dan kegiatan. Kedisiplinan yang paling terasa perubahannya adalah disiplin waktu, hal tersebut dapat dilihat dari pelaksanaan rapat yang selalu tepat waktu, lebih tertib, dan waktunya pasti. Menurut WBS, “...ketepatan waktu ketika hadir suatu meeting atau suatu 
pertemuan... “ (wawancara dengan WBS, 25 Juni 2012). DBP menambahkan disiplin tidak hanya disiplin waktunya saja tetapi prosedurnya juga jelas, dalam setiap rapat ada keputusannya, tidak ada yang tidak bisa diputuskan.

“...sekarang kalau ada rapat selalu tepat... kan sekarang di budaya yang baru tidak boleh rapat yang ditulis jam 08-selesai... nggak bisa, jadi harus jam 08 - jam 12...dan tidak ada yang tidak bisa diputuskan ...." (wawancara dengan DBP, 24 Januari 2012).

Pada budaya baru perusahaan memberlakukan sistem reward dan punishment, yakni memberikan penghargaanpenghargaan bagi mereka (karyawan) yang mempunyai prestasi kerja, serta memberikan hukuman bagi mereka yang melanggar peraturan baik peraturan tertulis maupun peraturan yang tidak tertulis tetapi hasil suatu kesepakatan bersama. Adapun reward yang diperoleh tidak harus berupa uang atau piagam penghargaan, bisa pula berupa benda yang kalau dilihat harganya tidak seberapa tetapi bisa duduk bersebelahan dengan direktur utama itu sudah merupakan kebanggaan bagi seorang karyawan.

Sementara punishment bisa denda berupa uang maupun hukuman lainnya, yang mana besaran dendanya berbeda antara karyawan atau manajer, direksi, dan komisaris. Adanya 'reward dan punishment' ditegaskan oleh Direktur SDM \& Administrasi, Epi Eriyana:

"Kami memberikan reward kepada karyawan berprestasi setiap satu tahun sekali dan karyawan teladan yang dilaksanakan triwulanan. Hal ini untuk mendorong motivasi dan memberi inspirasi kepada karyawan lain untuk dapat memberikan yang terbaik bagi perusahaan. Sedangkan punishment diberikan kepada karyawan yang melakukan pelanggaran sebagaimana diatur dalam peraturan perusahaan."

Pemberlakukan sistem ini harus dilaksanakan secara kontinyu, karena kalau sudah tidak diberlakukan lagi maka akan kembali pada perilaku yang semula, kecuali kalau perilaku itu memang sudah mendarah daging.

Pada budaya baru, efisiensi menjadi kebiasaan baru setelah dilaksanakan transformasi budaya, baik efisiensi terhadap pemakaian sesuatu maupun efisiensi terhadap waktu. Misalnya dalam rapat kalau ada suatu yang harus diputuskan harus diputuskan saat itu, jadi tidak mengulur-ngulur waktu, tidak mengambang tapi ada keputusannya, tidak perlu dirapatkan lagi untuk waktu berikutnya. Demikian pula dengan waktunya, waktunya jelas dari pukul sekian sampai pukul sekian tertera diundangan serta tepat waktu.

Dalam upaya menghadapi persaingan yang cukup ketat di antara perusahaanperusahaan yang memiliki bidang usaha sama, PT Dahana (Persero) melakukan berbagai pembenahan. Pembenahan tersebut diawali dengan melakukan perubahan logo, kemudian melakukan restrukturisasi organisasi termasuk di dalamnya restrukturisasi usaha, restrukturisasi keuangan, restrukturisasi sistem, dan pengembangan sumber daya manusia. Untuk itu, PT Dahana (Persero) mencoba menjadikan seluruh pegawainya memiliki kompetensi di bidangnya, sehingga apabila ada karyawan yang tidak memenuhi standar yang telah ditetapkan, akan diikutkan dalam berbagai pelatihan sesuai dengan kompetensi yang dibutuhkan. Dengan demikian, penggajian pun tidak lagi mengikuti aturan pegawai negeri tetapi berdasarkan kinerja, berdasarkan kompetensi, kenaikan pangkat tidak otomatis tetapi harus melalui assessment. YR selaku senior manager dari unit kerja Perencanaan Perusahaan dan Logistik menjelaskan bahwa sekarang penggajian berdasarkan kinerja. “...sistem penggajian berdasarkan kinerja meskipun belum berhasil seluruhnya..." (wawancara dengan YR, 26 Januari 2012).

Di tengah ketatnya persaingan, menciptakan perusahaan yang memiliki daya saing yang tinggi tidaklah mudah, untuk itu diperlukan usaha untuk melakukan pembenahan di berbagai bidang, yang salah satunya adalah pembenahan kompetensi sumber daya manusia. PT Dahana (Persero) termasuk salah satu perusahaan yang respek terhadap persaingan tersebut dengan upaya melakukan pembenahan sumber daya manusia karena menganggap persaingan ini 
sebagai tantangan yang harus dihadapi.

Untuk menciptakan perusahaan yang mempunyai produk yang berkualitas, tidak terlepas dari kompetensi sumber daya manusia yang terlibat di dalamnya. Untuk itu, PT Dahana (Persero) mencoba menjadikan seluruh karyawannya memiliki kompetensi di bidangnya. Salah satu usaha yang dilakukan untuk menghasilkan sumber daya manusia yang mempunyai kompetensi adalah menerapkan sistem antikorupsi, kolusi, dan nepotisme (KKN) dalam melakukan perekrutan karyawan. Seperti yang diungkapkan oleh Direktur SDM dan Administrasi, Epi Eriyana: "Kita melakukan perbaikan-perbaikan dalam segi rekrutmen, kita menerapkan anti KKN, sehingga diharapkan orang yang direkrut itu adalah orang-orang yang potensial" (wawancara dengan EE Desember 2010).

Penerapan sistem anti KKN dalam rekrutmen karyawan ini merupakan hal mendasar yang diterapkan PT Dahana (Persero). Tujuannya adalah menjadikan PT Dahana (Persero) sebagai perusahaan global player dan dapat berbicara kompetensi. Bagi karyawan yang tidak memenuhi standar yang ditetapkan, akan diikutkan dalam berbagai pelatihan sesuai dengan kompetensi yang dibutuhkan.

Berbicara kompetensi sumber daya manusia, tidak akan terlepas dari pendidikan yang sesuai dengan kebutuhan perusahaan, sehingga pendidikan memegang peranan penting dalam rekrutmen karyawan. Karyawan yang tidak mempunyai keterampilan yang sesuai dengan kebutuhan perusahaan akan tersisihkan oleh karyawan yang memang mempunyai kompetensi, sehingga akan ada karyawan yang merasa tersisihkan karena tidak mempunyai kompetensi. Seperti yang diungkapkan HND “...kalau sekarang SMA kontrak ga bakal diangkat karyawan..." (wawancara dengan HND, 26 Juni 2012). Mengenai tingkat pendidikan, EJ berpendapat bahwa pada budaya baru pendidikan itu diutamakan, seperti penuturannya:

“...budaya sekarang banyak yang ditujukan untuk kalangan atas, maksudnya menengah ke atas...ga terlalu mencolok, sekarang kelihatannya mencolok sekali..." (wawancara dengan EJ, 26 Juni 2012).

Unsur terpenting dalam proses perubahan budaya perusahaan tidak hanya pendidikan, keteladanan dari pimpinan pun memegang peranan penting. Seorang pemimpin adalah seseorang yang dapat memengaruhi kegiatan individu atau kelompok dalam usaha untuk mencapai tujuan dalam situasi tertentu. Oleh karena itu seorang pimpinan harus dapat memengaruhi dan menjadi contoh serta teladan bagi kelompok yang dipimpinnya. Salah satu peran pemimpin adalah sebagai teladan dan lambang. Kebaikan dan keburukan perilaku seorang pemimpin dapat menjadi panutan bagi yang dipimpinnya. Oleh karena itu, contoh atau teladan yang baik diharapkan dapat ditiru dan diikuti oleh yang dipimpinnya.

Dalam proses perubahan budaya perusahaan, seorang pimpinan yang baik tidak hanya menyuruh orang lain untuk berubah sementara dia sendiri tidak berubah, karena untuk melakukan suatu perubahan perlu figur. Berdasarkan penelitian dengan menggunakan metode kuantitatif terhadap tiga nilai budaya perusahaan (Nasionalisme, Kepemimpinan, Amanah, dan Layanan) yang dilaksanakan oleh unit kerja SDM pada tahun 2009 menunjukkan bahwa nilai budaya kepemimpinan mempunyai hasil yang kurang signifikan memberi pengaruh terhadap motivasi karyawan.

Untuk memperbaiki nilai kepemimpinan yang masih dianggap kurang, PT Dahana (Persero) melakukan berbagai upaya untuk memperbaikinya, salah satunya melalui latihan dasar kepemimpinan. Tanggal 28 Februari 2011, PT Dahana (Persero) mengadakan latihan dasar kepemimpinan untuk angkatan kedua. Latihan dasar tersebut dilaksanakan selama lima hari di PT Dahana Subang, Jawa Barat. Adapun yang menjadi tujuan dari pelatihan tersebut adalah untuk membina karakter peserta agar lebih disiplin dan mempunyai jiwa seorang pemimpin. (Majalah Internal D File No. 47, Maret 2011)

Budaya perusahaan sebagai realitas objektif dimaknai secara subjektif oleh seluruh anggota perusahaan melalui proses 
internalisasi, sehingga menimbulkan pemahaman yang berbeda di antara mereka. Demikian pula dengan pemahaman karyawan tentang budaya lama dan budaya baru perusahaan yang dimaknai secara berbeda. Ada yang memaknai secara positif dan ada yang memaknai secara negatif.

Berdasarkan Teori Konstruksi Sosial atas Realitas yang dikemukakan oleh Berger dan Luckman. Realitas subjektif memiliki dua dimensi khusus yang bersifat dialektik yaitu proses internalisasi dan eksternalisasi. Dalam proses internalisasi, individu menyerap nilainilai yang disosialisasikan oleh lingkungannya, namun tidak semua nilai dapat diserap dengan sempurna. Atas dasar tersebut maka individu dapat memaknai sebuah realitas dengan versinya sendiri yang dianggapnya sebagai cerminan dari realitas objektif.

\section{PENUTUP}

\section{Simpulan}

Pemahaman karyawan terhadap budaya lama perusahaan lebih banyak memiliki nilai budaya negatif yakni santai, birokrasi, kurang kompetitif, kurang client oriented, tidak berbasis kompetensi; dibandingkan nilai budaya yang positif yang menonjol yaitu kekeluargaan dan kepemimpinan.

Pemahaman karyawan terhadap budaya baru perusahaan lebih banyak nilai budaya yang positif yakni disiplin, adanya reward dan punishment, efisien, berdasarkan kompetensi, mengutamakan pendidikan; sementara nilai budaya yang negatifnya hanya satu yakni kurang adanya keteladanan.

\section{Saran}

Penelitian kualitatif dengan pendekatan etnografi komunikasi sebaiknya dilakukan terhadap kajian tentang budaya perusahaan, sehingga komponen-komponen komunikasi yang dianggap penting dalam etnografi komunikasi tidak dikupas dalam penelitian ini, seperti genre, setting, urutan tindakan, kaidah interaksi, dan norma-norma interpretasi dapat terungkap.
Penelitian tentang budaya perusahaan, sebaiknya dilakukan dengan paradigma kritis terutama berhubungan dengan kekuasaan, mengingat perusahaan bukan tempat netral untuk pembentukan makna.

Untuk mengimplementasikan suatu budaya baru perusahaan, diperlukan keteladanan dari para pimpinan yang biasanya dijadikan role of model sehingga bawahan akan mengikuti dan mencontoh apa yang dilakukan atasan berkaitan dengan penerapan nilai-nilai budaya.

Melakukan suatu transformasi budaya perusahaan merupakan suatu usaha tidak mudah dan memerlukan waktu yang relatif lama. Sebaiknya pihak perusahaan melakukannya secara terus menerus.

\section{DAFTAR PUSTAKA}

\section{Buku:}

Berger, Peter L, and Thomas Luckman. (1990). Tafsir Sosial atas Kenyataan. Terjemahan Hasan Basri dari The Social Contruction of Reality: A Treatise in the Sociology of Knowledge. Jakarta: LP3ES.

Bungin, H.M. Burhan. (2007). Penelitian Kualitatif. Jakarta: Kencana.

Kuswarno, Engkus. (2008). Metode Penelitian Komunikasi Etnografi Komunikasi. Bandung: Widya Padjadjaran.

Littlejohn, Stephen W. (2009). Teori Komunikasi. Theories of Human Communication. Jakarta: Salemba Humanika.

Mulyana, Deddy. (2001). Metodologi Penelitian Kualitatif. Bandung: Rosdakarya.

Moeljono, Djokosantoso. (2003). Budaya Korporat dan Keunggulan Korporasi. Jakarta: Gramedia.

Pace dan Faules. (2001). Komunikasi Organisasi. Strategi Meningkatkan Kinerja Perusahaan. Bandung: Remaja Karya.

Suprayogo, Imam dan Tobroni. (2001). Metodologi Penelitian Sosial-Agama. 
Bandung: Remadja Rosdakarya.

West, Richard and Lynn H. Turner. (2007). Introducing Communication Theory: Analysis and Application. New York: Mc Graw Hill.

Wibowo. (2010). Budaya Organisasi. Sebuah Kebutuhan untuk Meningkatkan Kinerja Jangka Panjang. Jakarta: PT Rajagrafindo Persada.

\section{Sumber lainnya :}

Hasil Raker. (2008). Paparan Budaya Perusahaan.Subang.

Majalah Internal D File no 44, Desember 2010 .

Majalah Internal D File no 47, Maret 2011. 